\title{
Lorenz Stoer and the Metaphor of Creative Power in Architecture
}

\author{
By Vladimir Mako*
}

\begin{abstract}
The aim of this paper is to investigate the possible meaning of Lorenz Stoer's woodcuts from the second half of the 16th Century, as particular metaphor of universal aspects regarding creative power in architectural design of the Mannerist époque. There is an indication that Stoer used metaphoric language to present, in a pictorial way, important thoughts of his time concerning new aesthetic premises of contemporary architecture emerging from the Renaissance legacy, interpreting the importance of the geometry as the link between natural laws and creativity. Stoer's pictorial reflection on philosophical aspects of aesthetic premises of new architecture of the time, can show the possible ways, how through a creative expression, new artistic values in becoming can be exposed and advocated.
\end{abstract}

\section{Introduction}

The sixteenth century culture of Western Europe has been an age of dominant search for new expressions in art and architecture. The Italian mannerist ideas seem to find ways of transforming the renaissance intellectual practice of continual development of ancient architectural legacy into particularly subjective visions of what new aesthetic manifestations in building activity can be. However, in comparison to the Italian mannerist ideas, establishing new aesthetic structuralism by using even temporal dynamic sense in architectural perception, in Germany the search in new architectural structures where often limited by understanding that ornamental principles of perceptional values, together with the use of proportional systems in architecture have been the main point of the new expression. In his book Institutionum geometricarum, Durer explains the importance for German architects to, according to the rules established by Vitruvius particularly regarding decorum, bring new expressions into their art. He appeals against monstrous ornamental forms, probably reflecting on Gothic architectural elements, asking from artists to apply the laws of proportion and antique orders. ${ }^{1}$

Durer's recommendation for applying new decorative systems in a search for contemporary architectural expression, developed as an idea through the whole sixteenth and seventeenth century in Germany and Nederland. In that context, proportional systems and decorum of five orders inherited from the antiquity and their transformation into new ornamental expressions, where emphasized as the main topic in many treatises on architecture, as for instance in Lossen's and Vredeman's, as in later Ditterlin's book at the end of the sixteenth

\footnotetext{
${ }^{*}$ Professor, University of Belgrade, Serbia.

1. A. Dureri, Institucionum geometricarum libri quatuor (Arnhemiae in Ducatu Geldriae, lib.III, 1605), 79, 82, 83.
} 
century. ${ }^{2}$ This practice continued through the early seventeenth century as in Krammer's book 1600, and in the treatise by Meyer and brothers de Bry in $1609 .{ }^{3}$ The later three artists insisted on beautiful inventions that are leading to the new manner in architecture, by applying the proportion system of five orders.

However, it seems that there was in action a particular feeling shaping the expressions of a new German architectural manner. For instance, we can reflect on Ditterlin's book which, at the end of the sixteenth century summarizes all important aspects of such a longing for a new aesthetic language. In a pictorial way, he was presenting many important ideas, even theoretical ones, regarding the very nature of architectural expression. As a compendium of all imaginable positions regarding the nature and logic of the art of building, Ditterlin presents, the importance of antique proportional systems and geometry, transforming them immediately into new ornamental patterns. He gives fascinating details of new decorum, and even fantastic illustrations regarding archetypal rustic appearance of architectural forms and their relationship to the antique orders. The relationship between old and new architectural forms was directly presented, and more than that, the idea that all these structures are directly springing of the nature itself, as a logical matrix of influential elements. The character of Ditterlin's work possibly reveals a pattern by which the sixteenth century thinking on architectural issues where established, and the number of important aspects can be emphasized: geometry, proportion, nature, the legacy of previous architectural ideas, and the importance of new authentic decorative and structural patterns.

However, it would be a wrong assumption to think that such an approach to new architectural values was superficial. In the essence of it one can recognize the search for new character and spirit of transformable aesthetic manifestation, able to incorporate different traditions and at that time modern understanding of the cultural and social purpose of architecture and art. It incorporated dynamic sense of intellectual and subjective perception of new cultural meanings, but growing on many of traditionally accepted philosophical and aesthetic values.

In that context, the use of metaphors in explaining new possible aesthetic values in architecture and art was a usual instrument. However, metaphor as a narrative form of expression is locked within the ideas of one particular culture and the time in which it flourishes. In order to be able to understand the ideas behind it, the metaphor should be carefully analyzed through recognizable cultural and aesthetic values according to which it was formed and expressed.

2. F. Lossen, Die Inventie der Colommen met haren coronementen ende maten (Antverpia, 1539); I. Vredeman Vriese, Architectura (Antverpiae, 1577); W. Ditterlin, Architectura von Aussthelung, Symmetria und Proportion der funf Seulen (Nurnberg, 1598).

3. G. Krammer, Architectura von dem funf Seulen sambtiren Ornamenten und zierdenals (Koln, 1600), 1, 5; D. Meyer, J. T. de Bry and J. I., Architectura (Frankfurt am Main, 1609). 


\section{The Woodcuts of Lorenz Stoer}

To the group of the sixteenth century German artists and architects expressing their particular interest in geometry and perspective, and of course in other important aspects just mentioned in the analysis of Ditterlin's work, belongs also Lorenz Stoer. In his book Geometria et perspectiva, published in Augsburg in 1567, Stoer presented personal imaginative artistic obsession with geometric solids, the art of perspective, lessons in ancient architecture, nature and human ingenuity, and from them composed new forms, basically influenced by work of other authors of its time. ${ }^{4}$ The main ideas and historical significance of Stoer's work has been already discussed and presented in the literature, and we will not comment the already known aspects of it. ${ }^{5}$

What we will pay attention on, is the possibility that Stoer, in his already well known eleven woodcuts, which he presented in the first part of his book as geometric solids in perspective among the architectural ruins, expressed a particular idea based on elements metaphorically speaking about creative power in architecture. It is from a particular interest that Stoer presented only images without any textual explanations or introduction. It seems that his approach in explaining the basic idea on the issue was based on, at that time recognizable motifs, some of which we already mentioned reflecting on Ditterlin's work. In that context, Stoer's visual expressions, seems to carry already known aspects, broadly accepted as aspects of architectural creativity.

The possibility of existence of such a metaphorical expression is based on the matrix by which these eleven woodcuts have been composed, and the repetition of motifs in their constant recognizable order. The first motif on which the composition of these woodcuts consists is representation of geometric solids, which character will be explained later. Geometric solids have been, in the sixteenth century treatises, usually closely related to the art of perspective, and in a way inseparable from them as presented to the audience. The second motif which generally appears in Stoer's woodcuts, Wood named as scrollwork, according to the term rollwerk used in German literature. ${ }^{6}$ The third compositional element can be identified as the images of trees and plants, incorporated within the representation of other motifs. Architectural ruins appear to be the forth, very important part of these woodcuts, carrying significant metaphorical meanings. However, it is not always clear do the architectural forms represent ruins or buildings in arising. As for the fifth motif one can think of the landscape with architectural forms in the background of all numbered compositional elements. There is just one appearance of the human figure in these compositions, and we will discuss its possible meaning later.

4. L. Stoer, Geometria et perspective (Augsburg, 1567).

5. D. Pfaff, Lorenz Stoer: Geometria et Perspectiva (Munchen: Magisterarbait. Fakultat fur Geshichts-und Kunstwissenschaften, Ludwig - Maximilians Universitat, 1996); C. Wood, The Perspective Treatise in Ruins: Lorenz Stoer, Geometria et Perspectiva, 1567. The Treatise on Perspective: Published and Unpublished (Newhaven and London: National Gallery of Art, Washington, Yale University Press, 2003), 235-257.

6. Ibid, 241; Pfaff, Lorenz Stoer: Geometria et Perspectiva, 13; A. Lichtwark, Der Ornamentstich der Deutschen Frurenessance (Berlin: Weidmannsche Buchhandlung, 1888), 15. 


\section{Geometric Solids and Perspective}

The main motif of these representations consists on geometric solids, first of all tetrahedron, octahedron, hexahedron, icosahedron and dodecahedron. In five woodcuts published in 1567, there are complex geometric forms composed out of other solids. They are all presented through the art of perspective, by which the title of the book reaches its full recognition. However, one should keep in mind that Stoer presented geometric solids in perspective according to rules used also by other authors of its time. In this context we should mention Lautensack, which book has been published in 1564, containing the same kind of representations of geometric forms in perspective. ${ }^{7}$ At this moment it is not clear enough why the sixteenth century authors used the complex geometric structures, composed out of two or more solids, in representing the art of perspective. However, this practice flourished mainly among architects and designers, and not in mathematical treatises of the time. Probably, there was an idea that if one learns to present complex forms in perspective all other tasks would be easier. Nevertheless, just a year after Stoer's book was issued, in 1568, Jammnitzer published his treatise, and in 1571, Lencker. ${ }^{8}$ All of them seem to use the same idea and practice of combining geometric solids and their perspective representation, with the high probability that they have been directly informed about each other's work.

The educational and practical importance of geometry, perspective and five basic geometric solids as fundamental corpora for composing other forms used in architecture and arts have been broadly emphasized in the sixteenth century German treatises. From the time of Durer, a few other German authors emphasized the educational importance of geometry. In Vogelin, and after him in Schmid, Dorrien and Oraeus, we can read how geometry is essential for the theoretical and practical work in arts and architecture. ${ }^{9}$ This standpoint emerges from the late renaissance discussion on the issue, particularly emphasized by Serlio and Scamozzi, which treatises have been known in the sixteenth century Germany.

Moreover, it seems that ideas regarding the five Platonic geometric solids as fundamental in the creation of the world, and consequently in architecture and arts, was also a popular topic at that time. Here we will mention two works that possibly influenced later authors on geometry and perspective by transmitting this Platonic tradition into the sixteenth century. In Champier and later in Rensbergen's and Jamnitzer's work, we can read about five geometric solids and their essential relationship to five elements, as generators of the world structure and its reflection on human creations. In his book, Jamnitzer even quoted Plato's

7. H. Lautensack, Des Circkels unnd Richtsheyts, aus Perspectiva (Frankfurt am Main, 1564).

8. W. Jamnitzer, Perspectiva corporum regularium (Nurnberg, 1568); H. Lencker, Perspectiva (Nurnberg, 1571).

9. J. Vogelin, Elementale geometricum ex Euclidis Geomentria (Argentorati, 1529); W. Schmid, J. F. Dorrien and H. Oraeus, Das erst Buch der Geometria (Nurnberg, 1539). 
Timaeus, carrying out the direct link with the ancient tradition. ${ }^{10}$ More than that, he illustrated the number of possibilities of developing the five Platonic solids into complex forms. However, despite the fact that in this way developed shapes where often more that different from their standard models, Jamnitzer thought that they preserve the basic characteristics of the origins. This is from a particular importance, particularly in defining a possible metaphorical meaning of such complex forms in their compositional appearance.

It seems that the importance of learning the characteristics and nature of Platonic regular forms and solids was basically supported by treatises on geometry in general, particularly by those emphasizing the practical role of the science. Besides already mentioned authors as Schmid, Dorrien and Oraeus, we should mention Hirschvogel, and a few non German writers as Fine and Peverone, contributing to the general discussion regarding the creative essence of geometry $^{11}$ (Figure 1). In this context we can even mention ideas developing the importance of using regular geometric forms in practical land measuring, as shown in Koebel's book from $1536 .{ }^{12}$ It illustrates an obsessive use of regular geometric forms in almost all human activities regarding measuring, land planning, and many other technical and artistic fields (Figure 2). This understanding of the importance of geometry seems to be directly related to the ideas of the Platonic tradition, by which all possible natural and human creations are emerging from the creative power of basic geometric solids.

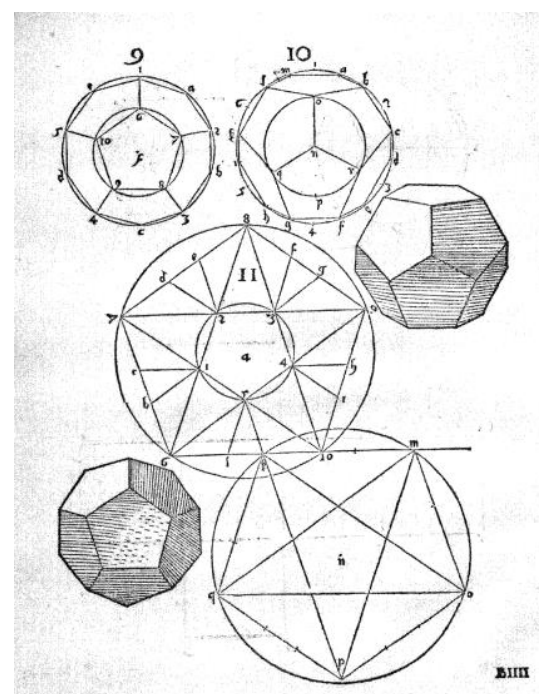

Figure 1. Hirschvogel, from his Book on Geometry, 1543

10. S. Champier, Symphoriani Champerii philosophy ac medici ingenio erudition eq sum (Basileae, 1537), 28, 32; N. Rensbergen, Geometria (Augspurg, 1568), 3, 4; Jamnitzer, Perspectiva corporum regularium; Pfaff, Lorenz Stoer: Geometria et Perspectiva, 33.

11. A. Hirschvogel, Ein aigentliche grundtliche anweysung in die Geometria sonderlich aber, wie alle regulierte und unregulierte Corpora, in der grundt gelegt und in das Perspectiff gebracht (Wien, 1543); O. Fine, Liber de geometria practica (Argentoratum, 1544), 106, 116, 123; G. F. Peverone, Due brevi e facile trattati,il primo d'Arithmetica, l'altro de Geometria (Lione, 1558), 71.

12. J. Koebel, Geometrei vonn kunstlichen Messen unnd absehen [S.I.], 1536. 




Figure 2. Koebel, from his Book on Land Measuring, 1536

From particular importance for our discussion is the idea exposed by many of mentioned authors, that mathematics in general has to be the fundament not only for the science of geometry, but also for perspective. However, it seems that the science of geometry was dominant over perspective, as the very essence of natural laws applicable in architecture and arts. On the front page of already mentioned Hirschvogel's book on geometry, we can read a verse emphasizing this idea

Das Buch geometria ist mein Namen

All freye Kunst aus mir zum ersten kamen

Ich bring Architectura und Perspectiva zusamen.

The book of geometry is my name

All free arts emerged from me in the first place

I bring architecture and perspective together.

According to this verse, geometry seems to be the source of characteristics equally for architecture and perspective, and their artistic appearance. By that, perspective shouldn't be understood as a tool in presenting forms and space, but a creative power based on its own rules, capable to enlarge the artistic effect of the artistic result, maybe even to form it completely. However, regarding our discussion, the sixteenth century idea of essential causality between geometry and perspective exceeds the level of such a poetic expression or idealistic interpretation. According to a few authors of the time, their relationship is rooted deeply in the nature of perception of the material world itself. This fact has been already discussed by Dorothea Pfaff, but we should remind on the importance of 
it. ${ }^{13}$ It refers to the form of pyramid with the sphere on its peak. This geometric composition was directly interpreted as the image of perceptual radial lines of the perspective system, where the sphere represented the eyeball. In the treatise written by Glogowczyk from 1506, de Sacrobosco from 1508, and Ryff from 1547 , we can find a direct explanation of this phenomenon. ${ }^{14}$

Compared with the appearance of pyramids and to them related spheres in Stoer's woodcuts, however, one can also think of an expression of another kind. Not only that the combination of mentioned solids can reflect on the issue of visualized essential law of the nature of perspective, but it seems that there was also a metaphorical consideration of their identification with the element of fire. Previously mentioned authors, according to Plato's ideas, already emphasized this metaphoric equality, but it seems that Stoer took a step further in developing a particular idea.

There are three woodcuts with the representation of pyramids in his book. In the first one we can find a pyramid which basis forms a star with six legs and behind it a four-sided one based on a square with the sphere on its peak. (Figure 3 ) In the second woodcut there is a pyramid with the sphere resting on its square base (Figure 4).

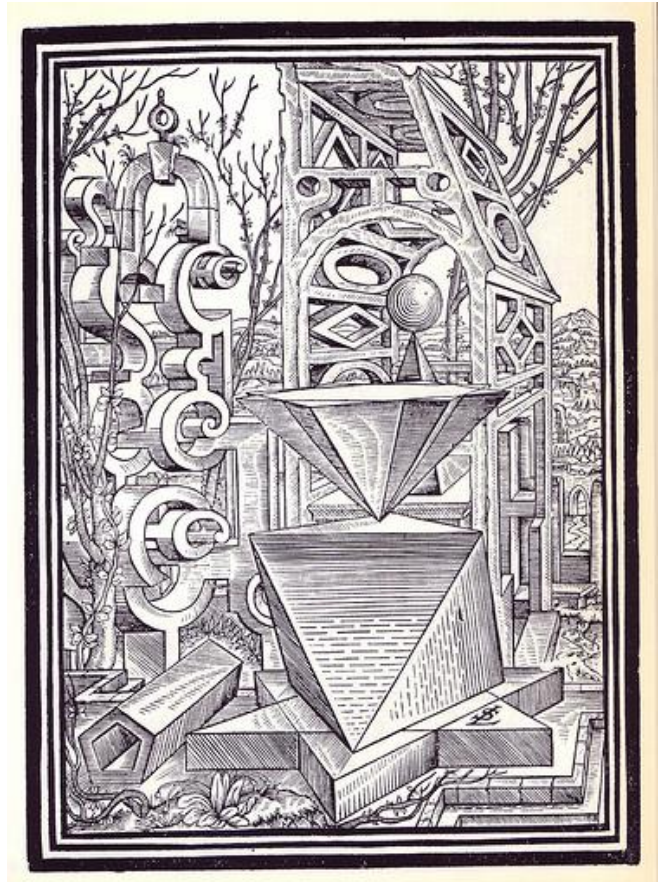

Figure 3. Stoer, from his Book on Geometry and Perspective, 1567

13. Pfaff, Lorenz Stoer: Geometria et Perspectiva, 15, 34.

14. J. Glogowczyk, Introductorium compendiosum in tractarum sphere material (Cracovia, 1506), 57, 58; J. De Sacrobosco, P. Ciruelo and P. de Aliaco, Uberrimum sphere mundi commentum Petri Circueely (Paris, 1508), 53; W. H. Ryff, Der furnembsten, notwendigsten der gantzen Architectur angehorigen mathematischen und mecanischen kunsteygentlicher Berichte (Nurnberg, 1547), 3-8. 


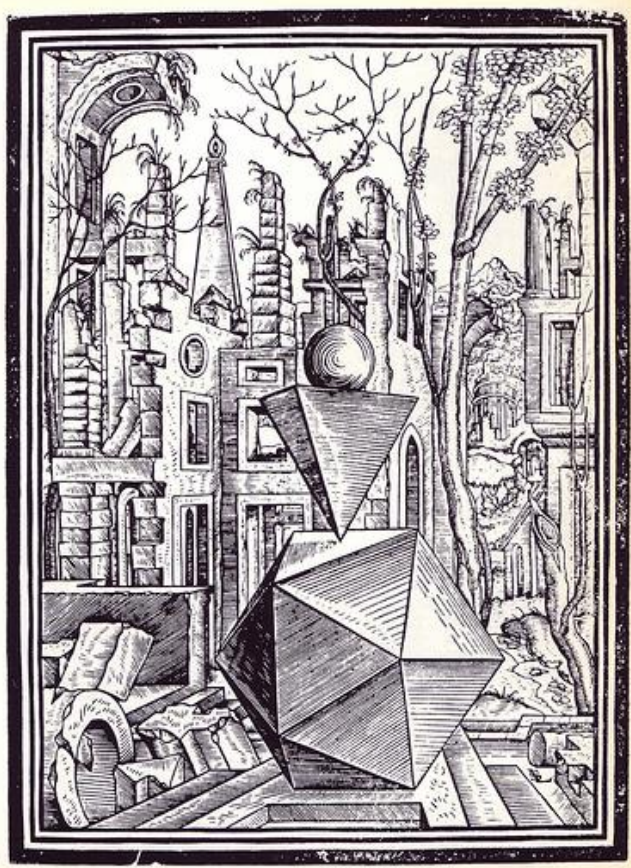

Figure 4. Stoer, from his Book on Geometry and Perspective, 1567

The third representation consists of two pervaded tetrahedrons, which interaction formed a complex geometric shape which can be also found in Jamnitzer's book. However, the other two representations also seem to indicate a potential interaction between pyramids and, to them related solids, by aiming their peaks toward an octahedron in the first one (similar to the example in Lautensack), and to icosahedron in the second one (Figure 5).

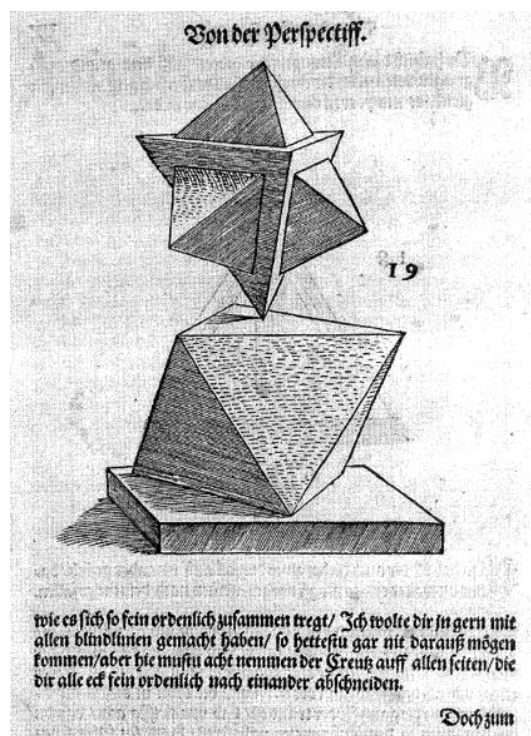

Figure 5. Lautensack, from his Book on Perspective, 1564

One can think on the activity of cutting and penetrating into the solids by pyramids. In other words, potentially it can refer on the process of releasing 
elemental creativity, explained in Plato's Timaeus, where fire is thought to be an active power in transforming and dividing other elements, through a basic interaction with them. ${ }^{15}$ However, this process can be activated also among other solids / elements, and by that Stoer's other combinations of forms can be justified by the same idea. However, only Stoer placed those geometric forms into a broader ideal context, accompanying to them other motifs important for our discussion.

\section{Scrollwork}

The second motif which appearance carries particular importance for the understanding of possible metaphorical meanings in Stoer's woodcuts is scrollwork. There are just two compositions not containing any scrollwork, and we will discuss them later. The nature of this motif has been generally recognized in the German literature as a decorative pattern, or a result in the basic German mannerist search for authentic ornamentation. ${ }^{16}$ Almost all sixteenth century German and Nederland treatises on architecture, and applied art in particular, are using ornamental pattern of scrollwork, in presenting the new decorative architectural and artistic expression of the time. The architects and artists in general have been inventors of new decorum. This notion was generally recognized also on the beginning of the seventeenth century, where in treatises culminated the idea of producing new pictorial values, often merging the classical and gothic decorative traditions. From already mentioned examples presented by Vredeman Vriese, and after him through Dietterlin's and Krammer's idea of direct causality between proportional systems of five orders and new architectural decorum, to Meyer's and de Bry's book, scrollwork dominated as an important part in defining the new character of contemporary decorative inventions in architecture (Figures 6, 7, 8 and 9).

15. Plato, Timaeus (New York: Macmillan and Co., 1888), Book 2, 53-58, 56d-e, 57a-b. 16. Lichtwark, Der Ornamentstich der Deutschen Frurenessance, 15ff; Pfaff. Lorenz Stoer: Geometria et Perspectiva, 13. 
Vol. 4, No. 1 Mako: Lorenz Stoer and the Metaphor of Creative Power...

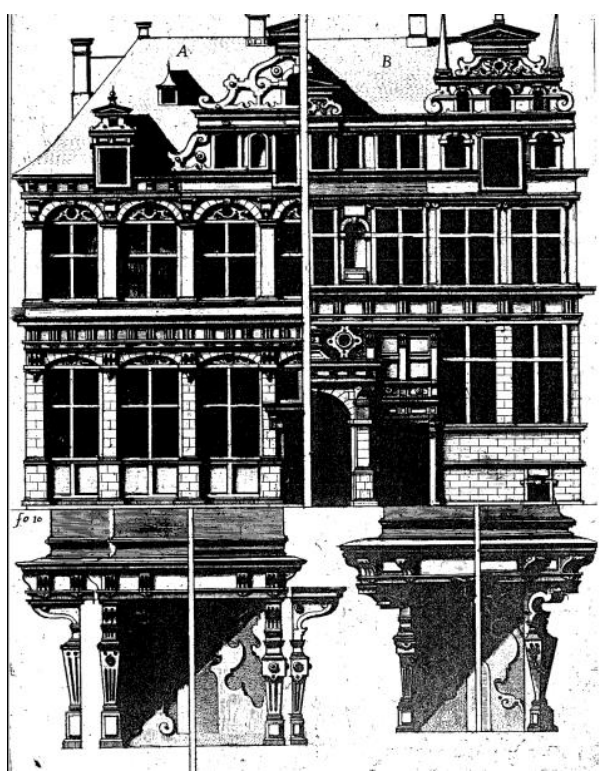

Figure 6. Vredeman Vriese, from his Book on Architecture, 1577

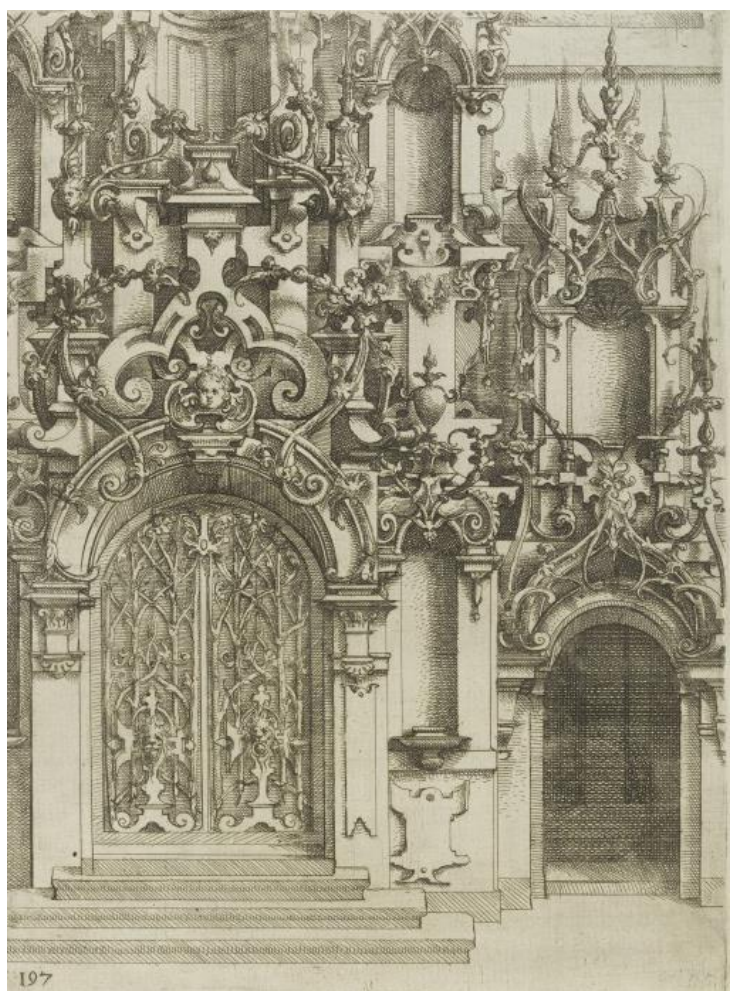

Figure 7. Dietterlin, from his Book on Architecture, 1598 


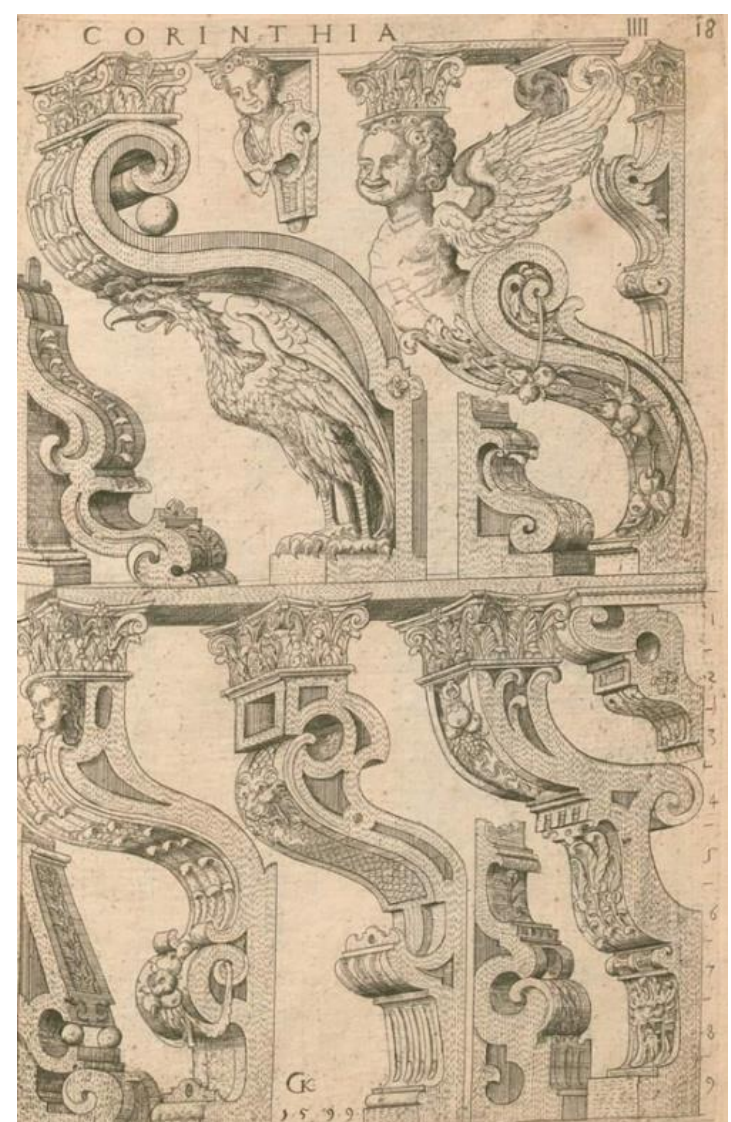

Figure 8. Krammer, from his Book on Architecture, 1600

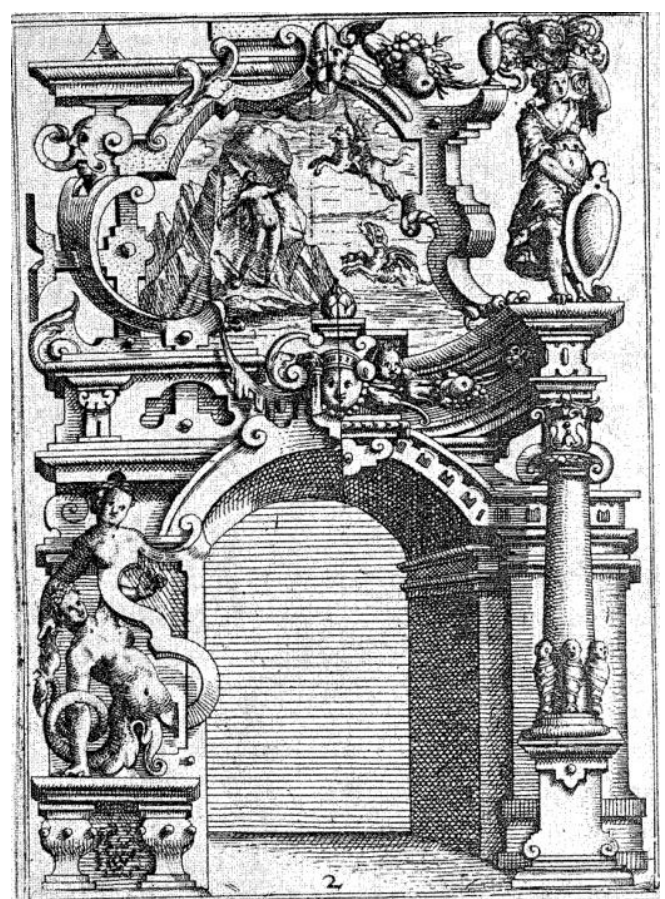

Figure 9. Meyer, from his Book on Architecture, 1609 
In this context scrollwork seems to be the essence of merging two important aspects of the new decorum. It has been understood as a product of the laws of geometry on one side, and natural forms as trees and plants on the other hand. One particular Stoer's woodcut, numbered as the eleventh, can show this exact kind of transformable process, where geometry/perspective and forms of plants are producing new decorative patterns. In it an octagonal shape, probably a well, is presented resting on a square base. On the steps in front of it two branches are placed, and a rose near the Lorenz Stoer's initials (Figure 10).

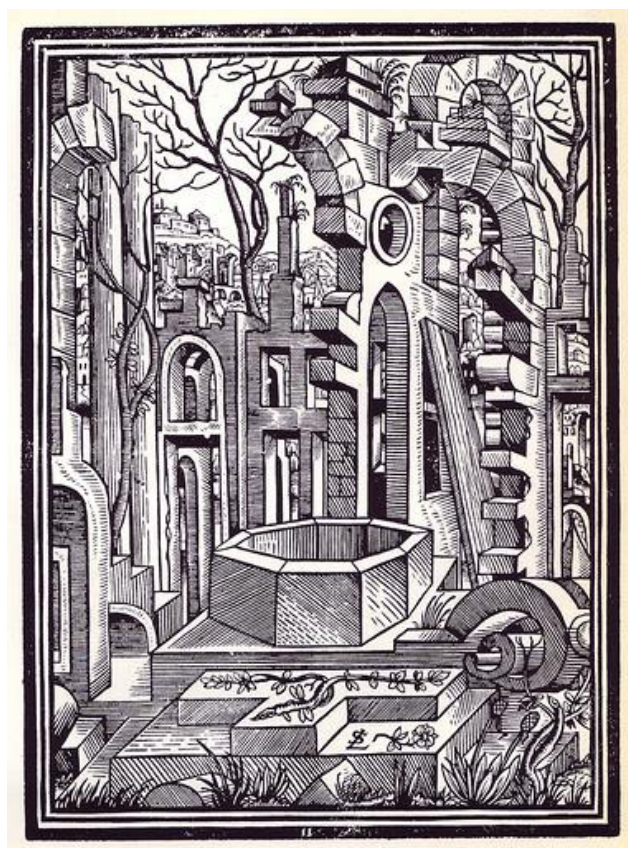

Figure 10. Stoer, from his Book on Geometry and Perspective, 1567

On the right side of the octagon, from its base a small piece of scrollwork is appearing, as an offspring of the new decorum. It is important to note that in his book, Ryff used exactly the same octagonal image to explain the importance of the science and art of geometry and perspective for representing the essential understanding of architecture. ${ }^{17}$ His argument has been enriched with a metaphorical comparison of the importance of this geometric form presented in perspective, with knowledge regarding the structure of human body. Although obscure, this comparison can indicate the significance of the image in Stoer's work. Moreover Stoer transforms the usual two dimensional scrollwork presented in other authors, into a three dimensional structure.

Of course, there was also the third source from which Stoer and other authors extracted these new ornamental inventions: the architecture of earlier traditions, particularly classical. In that sense, it is from a particular importance for our discussion that scrollwork incorporates all other motifs presented in Stoer's woodcut compositions. It is indicative that scrollwork in these

17. Ryff, Der furnembsten, notwendigsten der gantzen Architectur angehorigen mathematischen und mecanischen kunsteygentlicher Berichte, 24. 
compositions is transforming into a complex form containing elementary architectural parts of facades. A few of these structures are directly linked to the presented architecture in the background growing from walls and arches (Figures 11 and 12). They are forming inseparable unit, and by that contributing to the general feeling that these compositions are more than a picturesque scene.

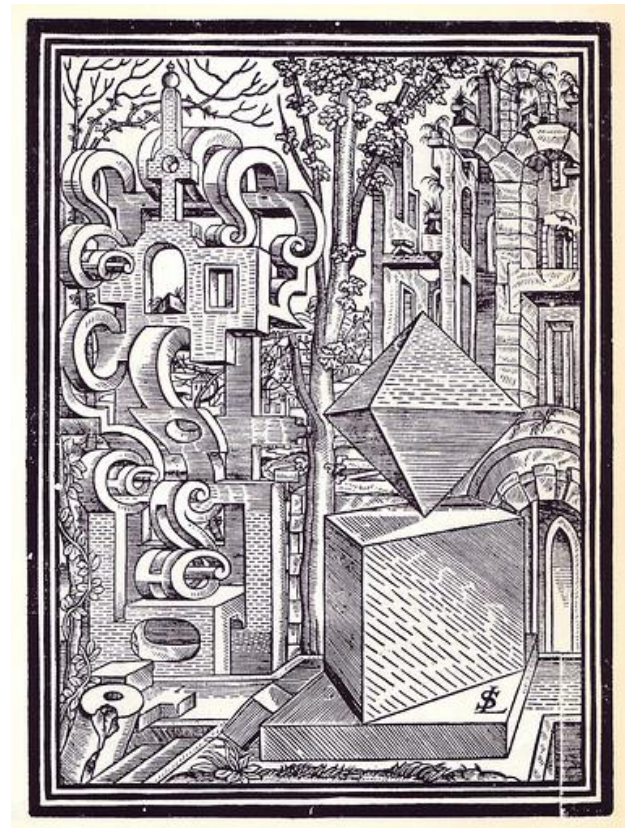

Figure 11. Stoer, from his Book on Geometry and Perspective, 1567

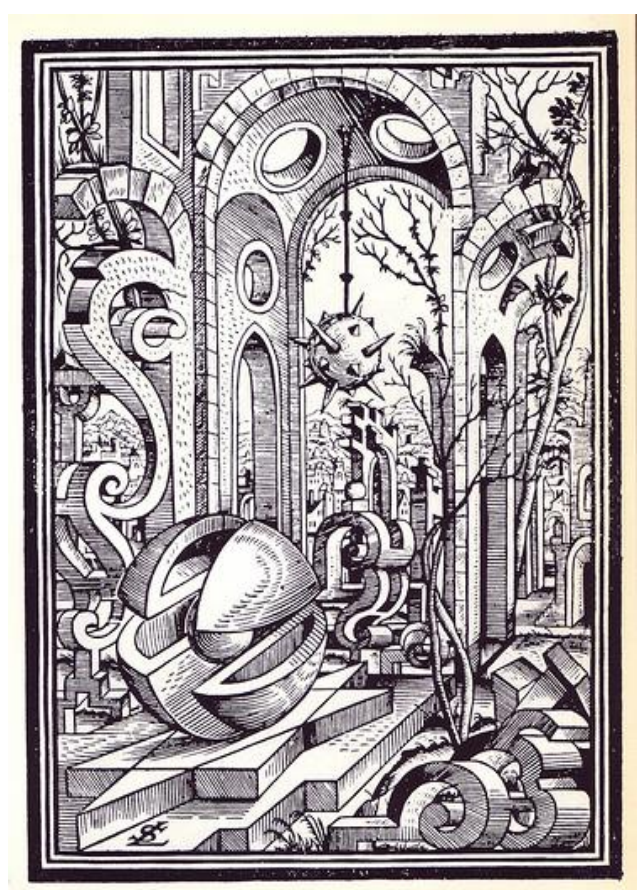

Figure 12. Stoer, from his Book on Geometry and Perspective, 1567 
The transformable nature of scrollwork incorporating many aspects of creative powers of geometry, perspective, natural and historical examples and models, seems that intentionally represents existence of a creative process shaping new architectural characteristics. Finalizing this process at the end of the sixteenth century, Ditterlin and Krammer directly developed an inventory form of new decorum, based on creative interaction of classical proportions, geometry and floral patterns (Figure 13).

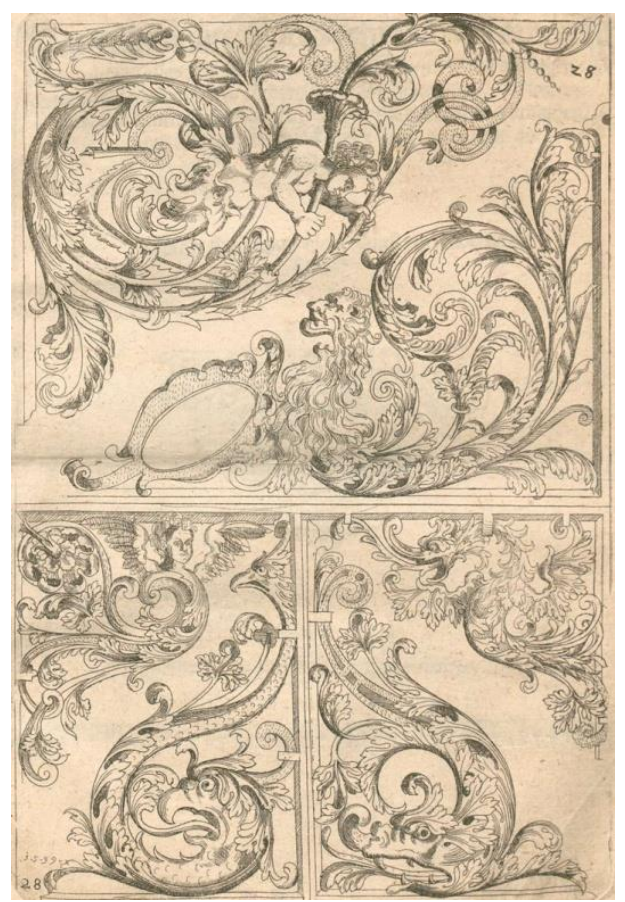

Figure 13. Krammer, from his Book on Architecture, 1600

\section{Representation of Architectural Forms}

In order to understand better this issue, we should take a closer look on the represented architectural forms in Stoer's woodcuts. Two examples important for our discussion are indicating different ideas regarding creative development of new architectural decorum. The first composition is the one of two which does not contain any scrollwork. There is a pure representation of architecture in ruins with an obelisk in the background. It is a perfect model of this kind of representation of the time broadly used by many authors (Figure 14). 


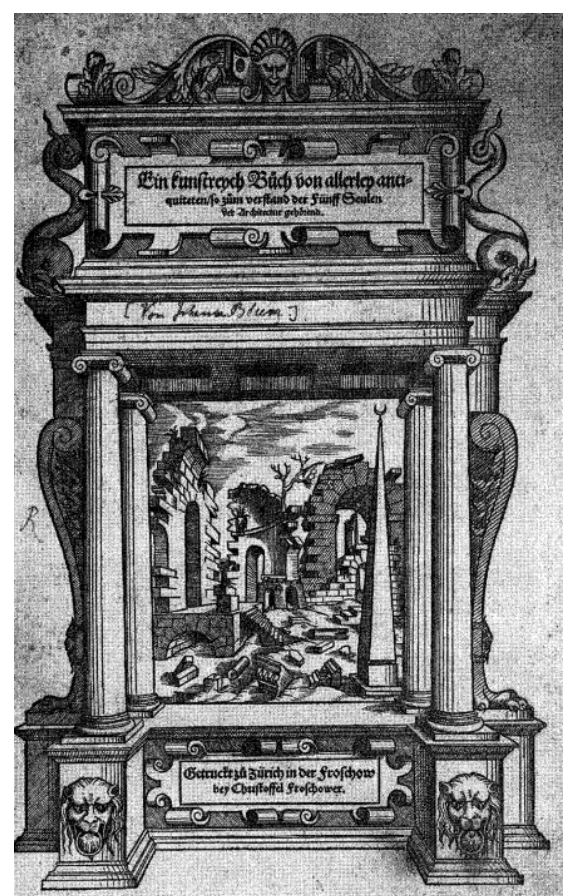

Figure 14. Blum, from his Book on Architecture, 1560

However, Stoer placed exactly into this scene a composition of solids that we have already discussed, emphasizing that the peak of the pyramid with the sphere resting on its base indicates the action of dividing the icosahedron. Translating the geometry of the solids into their Platonic elemental meanings, we can say that the element of fire which is positioned between the sphere of heavens above and the icosahedron of water below, initiates the beginning of the creative activity as the flame of genius.

The other woodcut contains the same obelisk, but with a radiating precious stone on it (Figure 15). On its left side there is a part of ancient ruin with a Doric column, and on its right side an architectural structure in a shape of mannerist decorative frame, similar to the example in another woodcut, where a pyramid with a sphere on its peak is resting inside such an architectural frame (Figure 3). The geometric solid is formed out of octahedron incorporated into a sphere, indicating the creative power of integration of elements, which results in rich scrollwork structure attached to architectural elements behind it. We should focus on the role of the obelisk as a metaphor of ancient times, traditionally symbolizing the presence of the power of sun, and in this example possibly reflecting the flame of a creative genius. If our assumption is correct, the architectural scenes in Stoer's work are playing an active role in forming metaphorical expressions regarding the representation of creative transformable process in forming new aesthetic characteristics. 


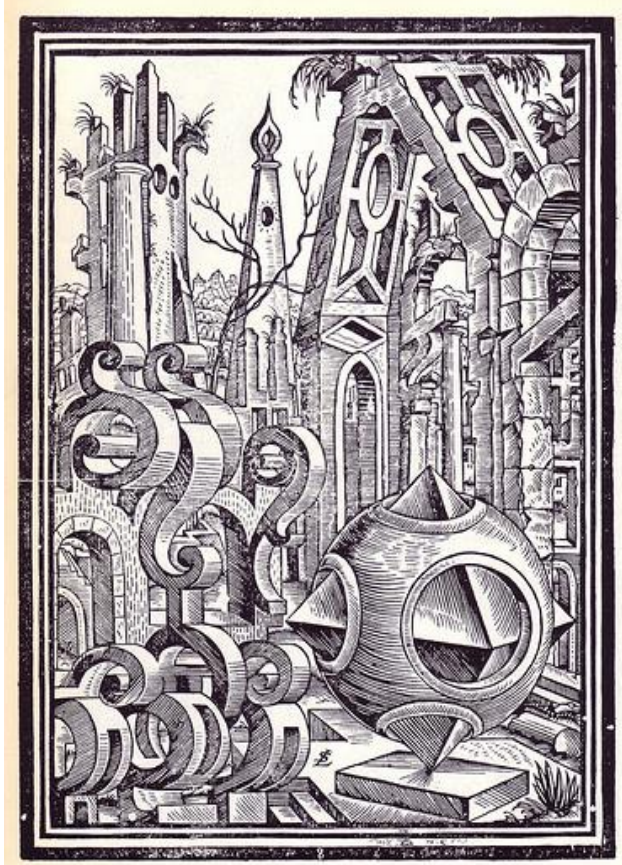

Figure 15. Stoer, from his Book on Geometry and Perspective, 1567

However, it seems that Stoer's woodcuts are not given in a successive order, developing the idea on creativity from one to another, by presenting stages in the process. The whole book is more arranged as an omnibus, by scenes with essentially similar narration, which allows for each of them to be interpreted through its own details and particular characteristics of applied motifs, particularly geometric solids and complex forms. Nevertheless, it seems that there is a strong ideal link between compositions. They emerge from the idea of a creative process which applies the Platonic interpretation of transformable power of basic geometric solids, strongly emphasized by Jamnitzer in the introduction of his book. He was also indicating the universal role of this process in forming all natural and human creations. Probably that is the reason why Stoer used the open landscape accompanied by building structures, destructed or in becoming. 


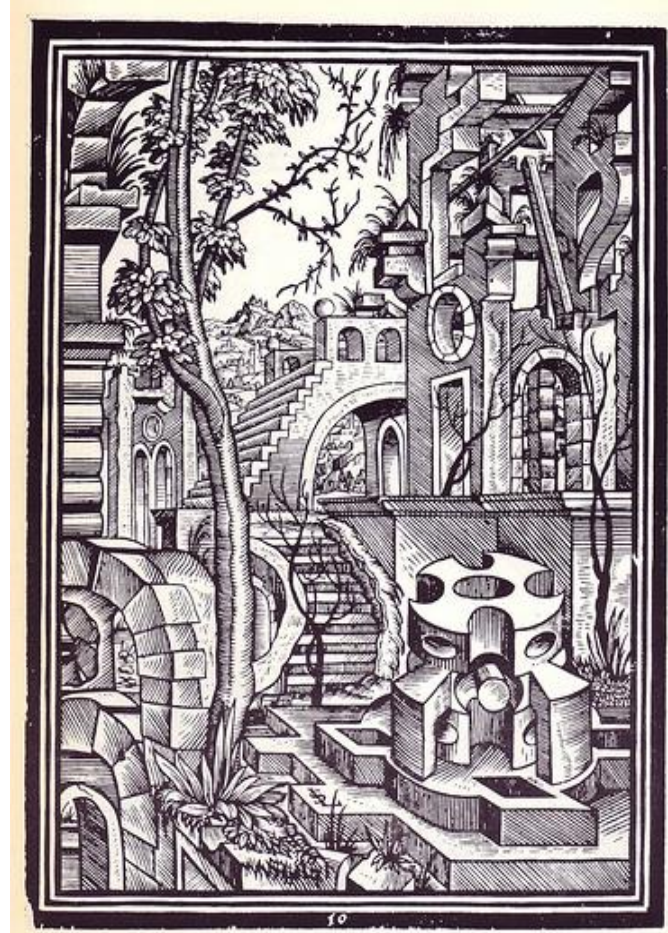

Figure 16. Stoer, from his Book on Geometry and Perspective, 1567

The complex forms presented in the woodcuts are exposing their inner structure comparable to new growing organisms. They are not a result of cutting larger solids into smaller particles by the essential 'natural logic of geometry. They seem to reflect on the presence of human creative genius, using the natural laws, but transforming it into new forms of architectural and artistic existence. The example of most developed complex geometric form we can find in the woodcut numbered as ten (Figure 16). It is also the second one without any scrollwork, but with dominant architectural elements in the background. The geometric solid shows characteristics of human products, mechanical or building forms, ${ }^{18}$ and its developed structure can possibly explain the absence of scrollwork. One can think on a final step of the creative process, where complex form with its own architectonics has been structured, and by that, the metaphor of the new decorum, the scrollwork, lost its significance.

\section{Conclusions}

In spite of the fact that in his woodcuts printed before and after those published in the book from 1567, Stoer presented human figures contemplating and disputing, like in renaissance time, on the importance, beauty and results of the use of geometric solids in creativity, in discussed examples there is just one, extremely discreet presence of a person.

18. Pfaff, Lorenz Stoer: Geometria et Perspectiva, 62. 
In the woodcut numbered as four, deep in the architectural background under the arch a small human figure is presented (Figure 17). Is it there as a witness of the creative power of geometry and nature, or a representative of human creative genius initiating the use of that power, we can just surmise. However, it is indicative that in this composition Stoer used geometric solids, dodecahedron and cube, actually the images of heaven and earth, which point of contact lies visually on the same line with the human figure. One can think of Stoer's idea that the human creative genius, resulting from the material world and heavenly spiritual wisdom, is able to use them equally on his own accord.

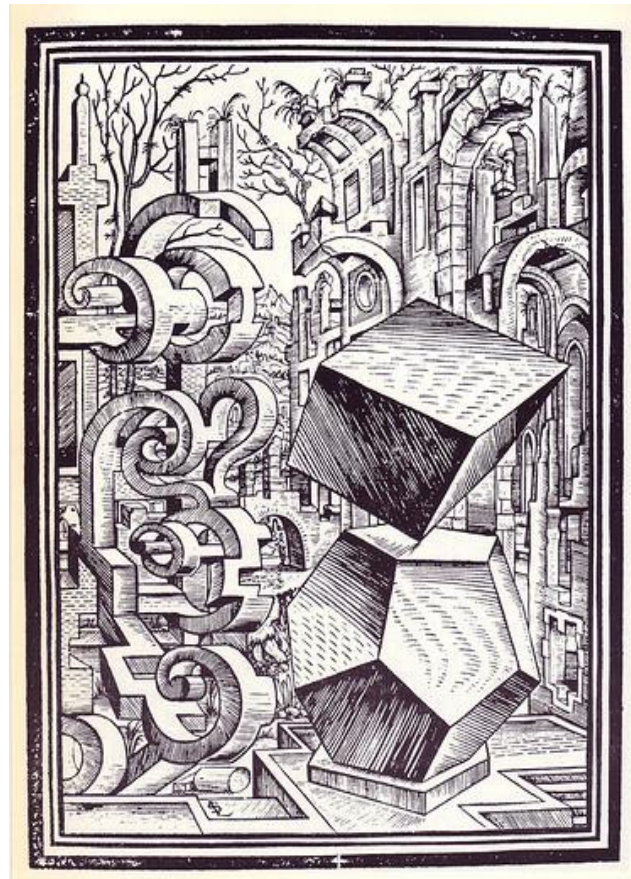

Figure 17. Stoer, from his Book on Geometry and Perspective, 1567

This tempting idea, maybe can find its strongpoint in an image, a cover page for the late fifteenth century book Antiquarie prospettiche Romane, attributed to Bramante (Figure 18). Here the author presented an athletic human figure, obviously idealized according to the classical aesthetic parameters, kneeling on the left knee. In the right hand the figure is holding an instrument, obviously for measuring the movement of heavenly bodies, and in the left a pair of compasses drawing down geometric shapes. The figure and the geometric drawings are represented within a circle, a symbol of unifying powers. Behind the human figure a tree is presented. At the right hand of the figure there is an architectural ruin, and on his left a new building structure. In the context of our discussion on Stoer's woodcuts and their potential metaphorical meaning regarding creativity in architecture, it seems that no further remarks on essential similarities between his compositions and presented Italian example should be elaborated. 




Figure 18. Bramante, the Cover Page for the Book Antiquarie, $15^{\text {th }}$ Century

However, there is still a perplexity remaining in our discussion. Was Stoer influenced by a particular artistic example, or inspired according to a generally accepted ideas and discussions on creativity, using recognizable motifs to give his own interpretation of the issue? Whatever the answer could be, we can think about existence of a broader discussion on this issue, which circulated among architects, artists, and intellectuals of the fifteenth and sixteenth century Western Europe, from which Stoer possibly extracted his own ideas and ways of presenting them to the audience.

\section{Bibliography}

Champier, S. Symphoriani Champerii philosophy ac medici ingenio erudition [Simphoriani Champier's Ingenious Philosophical and also Medical Erudition.] Basileae, 1537.

De Sacrobosco, J., P. Ciruelo and P. de Aliaco. Uberrimum sphere mundi commentum Petri Circueely [The Entire Comment on the World Sphere.] Paris, 1508, 53.

Ditterlin, W. Architectura von Aussthelung, Symmetria und Proportion der funf Seulen [On Architecture Exposed by Symmetry and Proportion of the Five Orders.] Nurnberg, 1598.

Dureri, A. Institutionum geometricarum libri quatuor [The Four Books on Geometry.] Arnhemiae in Ducatu Geldriae, 1605.

Fine, O. Liber de geometria practica [The Book on Practical Geometry.] Argentoratum, 1544.

Glogowczyk, J. Introductorium compendiosum in tractarum sphere material [The Introduction Compendium of the Treatise on Material Spheres.] Cracovia, 1506.

Hirschvogel, A. Ein aigentliche grundtliche anweysung in die Geometria sonderlich aber, wie alle regulierte und unregulierte Corpora, in der grundt gelegt und in das 
Perspectiff gebracht [A Proper Fundamental Order in Geometry Separated but, as all Regular and Irregular Bodies, in the Plan Positioned and in the Perspective Outlined.] Wien, 1543.

Jamnitzer, W. Perspectiva corporum regularium [On Regular Forms in Perspective.] Nurnberg, 1568.

Koebel, J. Geometrei vonn kunstlichen Messen unnd absehen [Geometry of Artistic Measure and Sight.] [S.I.], 1536.

Krammer, G. Architectura von dem funf Seulen sambtiren Ornamenten und zierdenals [On Architecture of the Five Order's Collected Ornaments and Ornamented look.] Koln, 1600.

Lautensack, H. Des Circkels unnd Richtsheyts, aus Perspectiva [The Circle and the Right work in Perspective.] Frankfurt am Main, 1564.

Lencker, H. Perspectiva [On Perspective.] Nurnberg, 1571.

Lichtwark, A. Der Ornamentstich der Deutschen Frurenessance [The ornamentation of the German Frurenessance.] Berlin: Weidmannsche Buchhandlung, 1888.

Lossen, F. Die Inventie der Colommen met haren coronementen ende maten [The Invention of Columns.] Antverpia, 1539.

Meyer, D., J. T. de Bry and J. I. Architectura [On Architecture.] Frankfurt am Main, 1609.

Peverone, G. F. Due brevi e facile trattati,il primo d'Arithmetica, l'altro de Geometria [Two Short and Gentle Treatises, the First One in Arithmetics and the Other One in Geometrics.] Lione, 1558.

Pfaff, D. Lorenz Stoer: Geometria et Perspectiva [Lorenz Stoer: Geometry and Perspective.] Munchen: Magisterarbait. Fakultat fur Geshichts-und Kunstwissenschaften, Ludwig - Maximilians Universitat, 1996.

Plato. Timaeus. New York: Macmillan and Co., 1888.

Rensbergen, N. Geometria [On Geometry.] Augspurg, 1568.

Ryff, W. H. Der furnembsten, notwendigsten der gantzen Architectur angehorigen mathematischen und mecanischen kunsteygentlicher Berichte [The Primal, and Necessary to Whole Architecture Belonging Mathematics and Mechanics Regulations.] Nurnberg, 1547.

Schmid, W., J. F. Dorrien and H. Oraeus. Das erst Buch der Geometria [The First Book on Geometry.] Nurnberg, 1539.

Stoer, L. Geometria et perspective [On Geometry and Perspective.] Augsburg, 1567.

Vogelin, J. Elementale geometricum ex Euclidis Geometria [On Elemental Geometry from the Euclid's Book on Geometry.] Argentorati, 1529.

Vredeman Vriese, I. Architectura [On Architecture.] Antverpiae, 1577.

Wood, C. The Perspective Treatise in Ruins: Lorenz Stoer, Geometria et Perspectiva, 1567. The Treatise on Perspective: Published and Unpublished. Newhaven and London: National Gallery of Art, Washington, Yale University Press, 2003. 